\title{
How Does Proactive Motivation Affect Job Crafting in Mamuju Hospitals?
}

\author{
Eka Fatmawati ${ }^{1}$, Indahwati Sidin ${ }^{2}$, Lalu Muhammad ${ }^{3}$ \\ ${ }^{1}$ Correspondence Author: ekafatmawati205@gmail.com \\ ${ }^{1}$ Hasanuddin university, Makassar, Indonesia \\ ${ }^{2}$ Hasanuddin university, Makassar, Indonesia
}

${ }^{3}$ Hasanuddin university, Makassar, Indonesia

I N D E X I N G A B S T R AC T

Keywords:

Proactive

Motivation;

Job Crafting;

Hospital

\begin{abstract}
Information about proactive motivation (PM) is important to hospital manager to predict the Job crafting (JC) behavior of hospital staff. High JC may lead to employee satisfaction and employee engagement at organization. Furthermore, it can improve staff performance and support the achievement of organizational goals. Individuals with proactive personalities are also most likely to change their work environment proactively. Motivation proactive can be generated by self efficacy and motivation internal. The purpose of this research was to analyze the ability of PM to stimulate JC behavior of hospital staff. This study was a cross sectional study. One hundred fifty five (155) staff was selected from 641 population in three (3) hospitals in Mamuju Regency. Data was analyzed by linear regression analysis. The research shows that $89 \%$ of sample had good PM and based on profession, more medical doctors had good PM than nurses. The bivariate analysis of PM and JC found that the p. value was 0,000 less than $\alpha$-value 0,05 . It means that statistically, PM influenced the JC. Proactive motivation affects job crafting by $16.2 \%$. When the hospital staff have high PM then the JC can be generated. The hospital manager should create working environment to foster PM among staff.
\end{abstract}

Kata kunci:

Motivasi proaktif;

Motivasi proaktif (MP) merupakan antesedent terciptanya Job crafting (JC) bagi petugas RS. JC yang tinggi dapat mengarah pada kepuasan karyawan dan keterlibatan karyawan di organisasi. Selanjutnya dapat meningkatkan kinerja staf dan mendukung pencapaian tujuan organisasi. Individu dengan kepribadian proaktif juga cenderung mengubah lingkungan kerja mereka secara proaktif. Motivasi proaktif dapat dihasilkan oleh efikasi diri dan motivasi internal. Penelitian ini bertujuan untuk melihat pengaruh MP terhadap JC. Penelitian ini menggunakan pendekatan cross-sectional. Populasi penelitian adalah 614 petugas RS di Mamuju district yaitu RSUD Kab. Mamuju, RS Bhayangkara Polda Sulbar dan RS Mitra Manakarra. jumlah sampel dalam penelitian ini sebanyak 155 orang. Pengaruh motivasi proaktif terhadap job crafting dianalisis dengan analisis regresi linier. Penelitian menunjukkan 89\% Sampel memiliki MP yang baik. Analisis regresi MP ke JC menunjukkan bahwa nilai $p$ adalah 0,000, lebih kecil dari nilai $\underline{\alpha}$ 0,05. Ini berarti bahwa secara statistik, MP mempengaruhi JC. Motivasi proaktif mempengaruhi kerajinan kerja sebesar 16,2\%. Semakin tinggi motivasi proaktif petugas maka akan semakin tinggi pula job crafting yang dimilikinya. Manajer rumah sakit harus menciptakan lingkungan kerja untuk mendorong motivasi proaktif di antara staf.

C 2020 JMMR. All rights reserved

Article history: Received 2020-11-25; Revised 2020-12-25; Accepted 2020-12-30

\section{INTRODUCTION}

The era of the industrial revolution 4.0 resulted in changes or disruptions in many lines, including in the assembly industry. Hospitals are faced with various complex challenges, especially related to human resources. HR is required to have a competitive advantage. One of the behaviors that support the increase in competitive advantage is work crafts or job crafting. Job crafting is a form of proactive work behavior that involves employees who actively change the characteristics (perceptions) of their work (Tims \& Bakker, 2010). Job crafting is a change made to maintain a balance between the expectations and desires of employees regardless of the work environment and existing resources. In 
addition, job crafting is a very important process to foster engagement and job satisfaction in a workforce that is experiencing increased job dissatisfaction and later fatigue (Berg, Dutton, \& Wrzesniewski, 2013).

Therefore, Rosso et al., Emphasize managers must focus on creating resources and a comfortable environment to promote job crafting (Rosso, Dekas, \& Wrzesniewski, 2010). There is also now a growing awareness that recognizes the need for health care professionals to take a proactive role in shaping their future work to improve the health care system (Gordon, Demerouti, Le Blanc, \& Bipp, 2015). Organizations can take advantage of job crafting as a way to strengthen organizational sustainability (Demerouti, 2014). Job crafting can contribute to organizational and employee sustainability in three different ways. First, job crafting can be used as a supplement to a job design approach to improve worker welfare and performance. Second, job crafting is a means that can be encouraged by organizations to make their employees enthusiastic and involved in their work. Third, job crafting can be a valuable means of tailoring jobs to the needs of a particular group of employees, for example, older employees, employees with disabilities or health problems, or parents with young children (Le Blanc, Demerouti, \& Bakker, 2017).

Basically, the focus of job crafting is that employees initiate and make changes in their jobs. This allows employees to increase the unique knowledge they have about their job and themselves to design their work in a way that creates more meaning (Berg et al., 2013). Wrzesniewski and Dutton (2001) introduced the concept of job crafting to capture "the actions employees take to shape, shape, and redefine their jobs" (Wrzesniewski \& Dutton, 2001). When they feel that their psychological needs are not being met in their work, individuals will be motivated to initiate changes in their tasks and job characteristics, which is known as job crafting (Bakker, Demerouti, \& Wang, 2016).

Research shows that people are motivated to be proactive when they experience three states of internal motivation: can do motivation, reason motivate or be energized for motivation. When people's experiences can do, reason, and energize motivation, it often gives them the courage and persistence to take the risks associated with being proactive (Parker, Bindl, \& Strauss, 2010).

Individuals with proactive personalities are also most likely to change their work environment proactively, by mobilizing job resources and job demands. This is consistent with Crant (2000), who argued that proactivity has a positive impact on employee performance because proactive individuals create opportunities for effectiveness. Job structuring facilitates engagement and, indirectly, performance, as employees who change their work environment proactively align their job demands and resources with their own abilities and needs (Tims \& Bakker, 2010). In the same vein, Greguras and Diefendorff (2010) suggest that proactive personality predicts role performance through satisfaction of needs (Greguras \& Diefendorff, 2010).

On this basis, proactive motivation is one of the important things in improving job crafting. Furthermore, the purpose of this research was to analyze the ability of PM to stimulate JC behavior of hospital staff. 


\section{RESEARCH METHOD}

This research is a cross sectional study. This research was conducted in December 2019 until March 2020. Population in this study were hospital officers in the Mamuju. Mamuju has 3 hospitals, namely: RSUD Mamuju District, Bhayangkara Hospital Polda Sulbar and Mitra Manakarra Hospital. They have 614 officers. Furthermore, 155 officers were selected who were willing to be samples in this study. Collecting data in this study using a questionnaire. The questionnaire used is a questionnaire that has been validated in previous studies and then translated into Indonesian. The variables used in this research are proactive motivation and job crafting.

Proactive motivation variables are measured using the Self-Efficacy Short Occupational variable developed and validated by (Rigotti, Schyns, \& Mohr, 2008) and The Situational Motivation Scale (SIMS) developed by (Guay, Vallerand, \& Blanchard, 2000). Proactive motivation is measured by two indicators, namely self-efficacy and intrinsic motivation. Job Crafting is measured using the Job Crafting Questioner developed by (Tims, Bakker, \& Derks, 2013). Job crafting is measured by four indicators, namely increasing structural work resources, reducing obstructing job demands, increasing social work resources and increasing challenging job demands.

The data analysis used was univariate and bivariate analysis. Univariat is used to see the frequency distribution of the characteristics of the respondents in this study. Furthermore, the bivariate analysis used is linear regression analysis.

\section{RESULT AND DISCUSSION}

Proactive motivation in this research is things that encourage employees to carry out proactive activities. Proactive motivation is then analyzed for its effect on job crafting. The following are the results of the frequency analysis of proactive motivation and job crafting for hospital staff as follows:

Table. 1 Description of the perception of proactive motivation and Job crafting on hospital employees in Mamuju district 2020

\begin{tabular}{llcc}
\hline Variable & Category & $\mathbf{n}$ & \% \\
\hline Proactive Motivation & Less & 17 & 11.0 \\
& Well & 138 & 89.0 \\
Job crafting & Less & 22 & 14.2 \\
& Well & 133 & 85.8 \\
\hline
\end{tabular}

Source: Primary data

Based on the table.1, it is known that the average respondent has a fairly good proactive motivation, namely 138 people $(89 \%)$. There were 17 respondents with poor proactive motivation category $(11 \%)$. On the Job Crafting Indicator, the average respondent has a fairly good job crafting, namely 133 people (85.8\%). The respondents with the poor job crafting category were 22 people (14.2\%). 
Table.2 Distribution of the proportion of proactive motivation towards Job Crafting employees of rs in Mamuju district 2020

\begin{tabular}{|c|c|c|c|c|}
\hline \multirow[t]{3}{*}{ Variabel } & \multicolumn{4}{|c|}{ Job Crafting } \\
\hline & \multicolumn{2}{|c|}{ Less } & \multicolumn{2}{|c|}{ Well } \\
\hline & $\mathrm{N}$ & $\%$ & $\mathbf{n}$ & $\%$ \\
\hline Proactive motivation Less & 11 & $64,7 \%$ & 6 & $35,3 \%$ \\
\hline Proactive motivation Good & 11 & $8 \%$ & 127 & $92 \%$ \\
\hline
\end{tabular}

Source: Primary data

The results of cross tabulation showed that $64.7 \%$ of officers who had less proactive motivation also had less job crafting, the remaining $35.3 \%$ had good job crafting. Low proactive motivation is dominated by low intrinsic motivation, only $67.1 \%$ think that modifying work is something interesting and only $70 \%$ feel better when doing work creativity.

As $92 \%$ of officers who have good proactive motivation also have good job crafting. Proactive motivation in this study is measured using self-efficacy and intrinsic motivation. Self-efficacy is the belief in the ability and work skills of employees that are able to support competitiveness. At the organizational level, employee contributions have an influence on employee performance. Psychological factors in general will have an impact on positive things and efforts to make employees able to work optimally (Setyawan, 2019).

The most powerful reason for being proactive comes from 'inside', or what is known as internalized or intrinsic motivation. This also refers to self-determination theory which states that proactive behavior is autonomous (self-initiated) rather than being regulated externally by contingencies outside the person, so this is what drives the proactive goal process (Parker et al., 2010).

The following are the results of linear regression analysis on proactive motivation for job crafting hospital staff in Mamuju district;

Table.3 Linear Regression F Test Results

\begin{tabular}{|c|c|c|c|c|c|}
\hline Model & Sum of Squares & $\mathrm{dF}$ & Mean Squared & $\mathrm{F}$ & P value \\
\hline Regression & 764.048 & 1 & 764.048 & 29.584 & $.000^{\mathrm{a}}$ \\
\hline Residual & 3951.462 & 153 & 25.827 & & \\
\hline Total & 4715.510 & 154 & & & \\
\hline
\end{tabular}

Table. 3 shows the $F$ value resulting from a simple regression analysis of 29.584 with a $p$ value of 0.000 . $\mathrm{P}$ value $<0.05$, these results prove that there is a significant effect on job crafting.

Table.4 Results of the simple linear regression determination test

\begin{tabular}{lrrrrr}
\hline Model & R & R Square & Adjusted R Square & Std. Error of the Estimate \\
\hline 1 & & $.403^{\mathrm{a}}$ & .162 & .157 & 5.08198 \\
\hline Source: Primary data & & & & &
\end{tabular}


Table.4 shows that the R2 value generated from simple linear regression analysis is 0.162 , which means that $16.2 \%$ of proactive motivation variables can predict job crafting. The remaining $83.8 \%$ is another factor that is not explained in this study.

Table.5 Simple Linear Regression $\mathrm{t}$ test

\begin{tabular}{cccccc}
\multicolumn{2}{l}{ Table.5 Simple Linear Regression $\mathrm{t}$ test } & & & \\
\hline Model & Unstandardized coefficients & Standardized coefficients & T & P value \\
& B & Std. Error & Beta & & \\
\hline (Constant) & 42.121 & 2.460 & & 17.122 & .000 \\
MPX1 & .428 & .079 & .403 & 5.439 & .000 \\
\hline
\end{tabular}

Source: Primary data

Table.5 illustrates the linear regression line equation in this study. The equation of the line is Job crafting $=42,121+0,428$ (Proactive Motivation). This means that if there is no proactive motivation value, the amount of job crafting is 42,121 units. Every addition of 1 unit of proactive motivation value will increase job crafting by 0.428 . Proactive motivation contributes positively to the job crafting of officers. This means that the more positive the perceived proactive motivation, the higher the job crafting will be.

The results of this study are in line with the research of Bakker, Tims and Derks on 190 employees in various organizations which concluded that employees with proactive personalities will design their own work (job crafting) (Bakker, Tims, \& Derks, 2012). Li, jin and chen also revealed that proactive personality is positively related to job crafting, the results of the study show that when human resource management involves less participatory management, incentive rewards, extensive training and information sharing, proactive employees can take advantage of their personalities to structure tasks, their relationships, and occupational cognition ( $\mathrm{Li}$, Jin, \& Chen, 2020). In line with this research, the low level of job crafting is dominated by indicators of reducing the obstructing job demands. Many respondents who do not try to manage their work affect their emotions and concentration.

The research is in line with research conducted by Kim (2018), this research shows that self-efficacy is a predictor of job crafting. The more employees believe they have the ability to achieve creative results, the more they initiate changes in the tasks they perform, their relationships with other people at work, and their perceptions of their work (Kim, Im, \& Qu, 2018).

Some researchers also mention that certain individuals are more likely to redesign their work than others (Bakker et al., 2012; Petrou \& Demerouti, 2015). Employees may be motivated to design their jobs to proactively prepare for future job changes. For example, they can expand their duties and relational environment by increasing the scope of job responsibilities or increasing the amount of communication with people in the workplace to get more information. As a result, job crafting can help employees easily cope with job changes and uncertainties in the future (Wang, Demerouti, Blanc, \& Lu, 2018).

The more important someone places on certain needs, the stronger those needs are, and the more someone will be motivated to satisfy them (Sheldon \& Gunz, 2009). Individual needs must be very important to motivate engagement in work crafts (Wrzesniewski \& 
Dutton, 2001), so that the forces required drive active employee change in their work in a way that will meet the individual's needs.

Lynn Beer (2016) also states that if a position is developed in which several limits on roles and responsibilities need to be tested and adjusted, an individual who has a highly proactive personality is likely to develop more work and potentially help in increasing the core role of that job and being more responsible answer (Beer, 2016) (Beer, 2016).

\section{CONCLUSION}

The effect of proactive motivation on job crafting is significant. These results prove that the higher the proactive motivation, the higher the job crafting will be. Proactive motivation and job crafting need to be considered so that human resources in the hospital can work as much as possible and can also increase staff job satisfaction. This is certainly expected to have an impact on the productivity of hospital staff. It is recommended to examine with the same variables in another hospital. Future studies should also analyze manifest or indicator variables so that they can be discussed in more depth and detail.

\section{REFERENCE}

Bakker, A. B., Demerouti, E., \& Wang, H. (2016). A Review of Job-Crafting Research: The Role of Leader Behaviors in Cultivating Successful Job Crafters Proactivity at work (pp. 95-122): Routledge.

Bakker, A. B., Tims, M., \& Derks, D. (2012). Proactive personality and job performance: The role of job crafting and work engagement. Human relations, 65(10), 1359-1378.

Beer, L. (2016). The motivation and capability to job craft. Kansas State University.

Berg, J. M., Dutton, J. E., \& Wrzesniewski, A. (2013). Job crafting and meaningful work. Purpose and meaning in the workplace, 81, 104.

Demerouti, E. (2014). Design your own job through job crafting. European Psychologist.

Gordon, H. J., Demerouti, E., Le Blanc, P. M., \& Bipp, T. (2015). Job crafting and performance of Dutch and American health care professionals. Journal of Personnel Psychology.

Greguras, G. J., \& Diefendorff, J. M. (2010). Why does proactive personality predict employee life satisfaction and work behaviors? A field investigation of the mediating role of the self-concordance model. Personnel Psychology, 63(3), 539-560.

Guay, F., Vallerand, R. J., \& Blanchard, C. (2000). On the assessment of situational intrinsic and extrinsic motivation: The Situational Motivation Scale (SIMS). Motivation and emotion, 24(3), 175-213.

Kim, H., Im, J., \& Qu, H. (2018). Exploring antecedents and consequences of job crafting. International Journal of Hospitality Management, 75, 18-26.

Le Blanc, P. M., Demerouti, E., \& Bakker, A. B. (2017). Better? Job Crafting for Sustainable Employees and Organizations. An introduction to work and organizational psychology: An international perspective, 48.

Li, H., Jin, H., \& Chen, T. (2020). Linking proactive personality to creative performance: The role of job crafting and high-involvement work systems. The Journal of Creative Behavior, 54(1), 196210.

Parker, S. K., Bindl, U. K., \& Strauss, K. (2010). Making things happen: A model of proactive motivation. Journal of management, 36(4), 827-856.

Petrou, P., \& Demerouti, E. (2015). Trait-level and week-level regulatory focus as a motivation to craft a job. Career Development International, 20(2), 102-118. 
Rigotti, T., Schyns, B., \& Mohr, G. (2008). A short version of the occupational self-efficacy scale: Structural and construct validity across five countries. Journal of Career Assessment, 16(2), 238 255.

Rosso, B. D., Dekas, K. H., \& Wrzesniewski, A. (2010). On the meaning of work: A theoretical integration and review. Research in organizational behavior, 30, 91-127.

Setyawan, A. A. (2019). Pengaruh Psychological Capital Terhadap Career Success Dengan Job Crafting Sebagai Variabel Mediasi. Jurnal Manajemen dan Pemasaran Jasa, 12(2), 225-236.

Sheldon, K. M., \& Gunz, A. (2009). Psychological needs as basic motives, not just experiential requirements. Journal of personality, 77(5), 1467-1492.

Tims, M., \& Bakker, A. B. (2010). Job crafting: Towards a new model of individual job redesign. SA Journal of Industrial Psychology, 36(2), 1-9.

Tims, M., Bakker, A. B., \& Derks, D. (2013). The impact of job crafting on job demands, job resources, and well-being. Journal of Occupational Health Psychology, 18(2), 230.

Wang, H. J., Demerouti, E., Blanc, P. L., \& Lu, C. Q. (2018). Crafting a job in 'tough times': When being proactive is positively related to work attachment. Journal of Occupational and Organizational Psychology, 91(3), 569-590.

Wrzesniewski, A., \& Dutton, J. E. (2001). Crafting a job: Revisioning employees as active crafters of their work. Academy of management review, 26(2), 179-201. 